\title{
CROPPED IMAGES
}

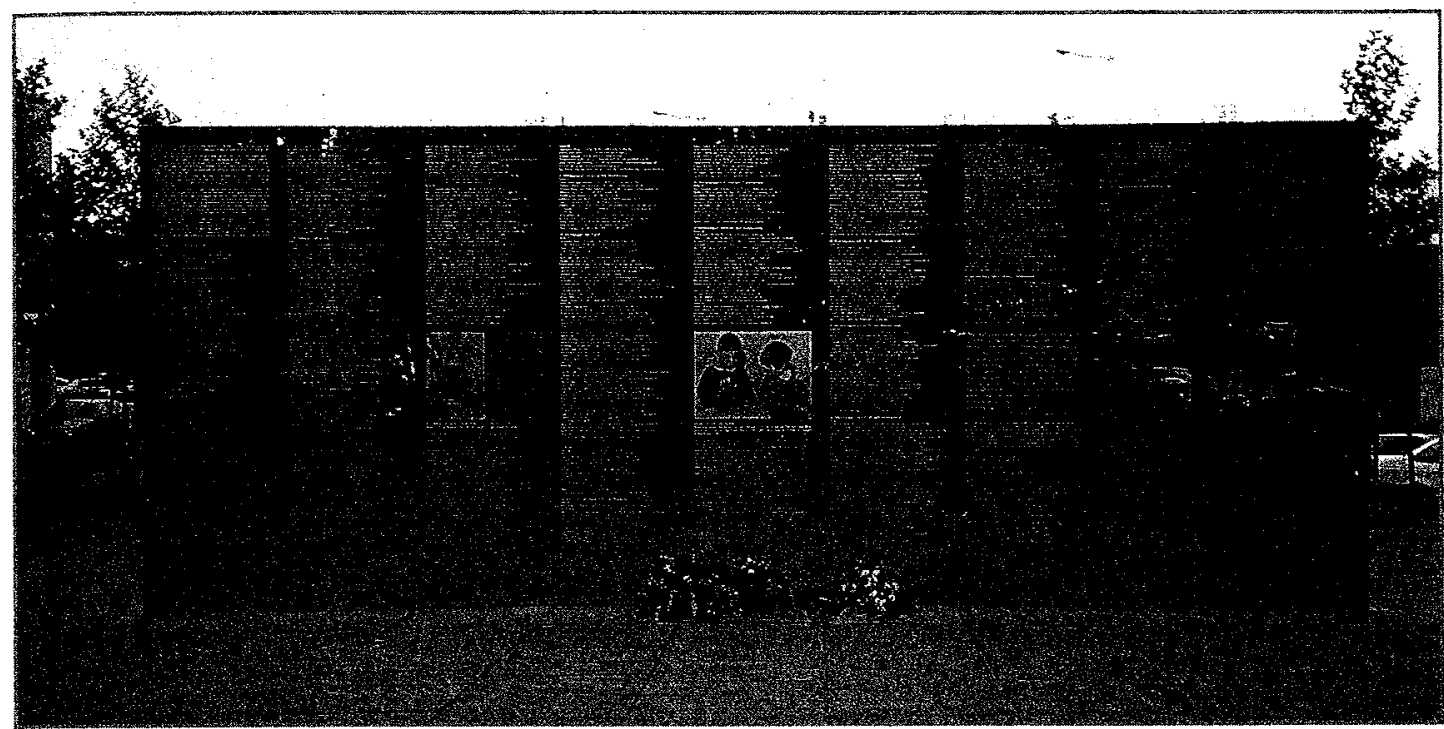

The image reproduced above depicts a holocaust memorial on Hermann-EhlersPlatz in Berlin-Steglitz, a suburb of Berlin (formerly, of West Berlin). The so-called Spiegelwand (mirror wall) is inscribed with the names, dates of birth and local addresses of 230 Jewish inhabitants of Steglitz who were deported to ghettos and concentration camps between $194^{2}$ and I945.' It is one of numerous memorials which have been built since the early I 980 s in the Federal Republic of Germany to commemorate the victims of Nazi Germany. This proliferation of public memories of the Nazi past-given material form in museums and monuments-is specific to Germany, but it is also a symptom of what Andreas Huyssen has called the 'memory boom' of the past two decades. ${ }^{2}$
The memory boom has sparked a boom in memorial criticism, that is, in critical readings of tangible manifestations of public memory. I could now adopt the role of the memorial critic and embark on a semiotic reading of the Spiegelwand. You would be able to critique my interpretation on the basis of having an idea of what the memorial looks like. In a sense, what I would then be doing would be the equivalent of interpreting a poem as well as reading it. But wouldn't I be cheating by presenting only this image?

There are many other angles from which I could have depicted the mirror wall. While taking pictures of the memorial, my angle of vision was much wider than that of my camera. By illustrating a semiotic reading of the Spiegelwand with the image reproduced above, I may be pretending that the view encapsulated in it is the view that allowed me (and, by 
extension, my readers) to grasp the meaning and significance of the memorial. A wider angle, after all, would include other aspects of Hermann-Ehlers-Platz, which presumably do not belong to the memorial.

In most cases, the person interpreting a poem would only have to read it out to allow her audience to appreciate her interpretation. She may of course contextualize the poem by referring to related works of literature or to the historical circumstances of its creation. Rarely would she mention the typeface of the edition she read. She would not describe the texture of the paper on which the poem is printed, nor the table on which her arms rested while she savoured the poem for the first time. How useful is it to 'read' memorials as if they were texts? Is the difference between what I could see . when taking this photo, and what is depicted on the photo, irrelevant to an interpretation of the memorial?

While looking at many different memorials throughout Germany, I became increasingly worried about what usually gets left out in readings of memorials. Although I was initially not able to put my finger on why exactly I was worried, my worry turned into an obsessive longing to document and grasp the seemingly superfluous contexts of memorial texts. I became obsessed with such contexts to the extent that memorials themselves sometimes mattered less to me than their seemingly irrelevant surroundings. My heart beat faster when I felt that these surroundings talked to me, revealed themselves as part of a memorial ensemble.

The city of Hannover also has a holocaust memorial. It displays the names of $189^{2}$

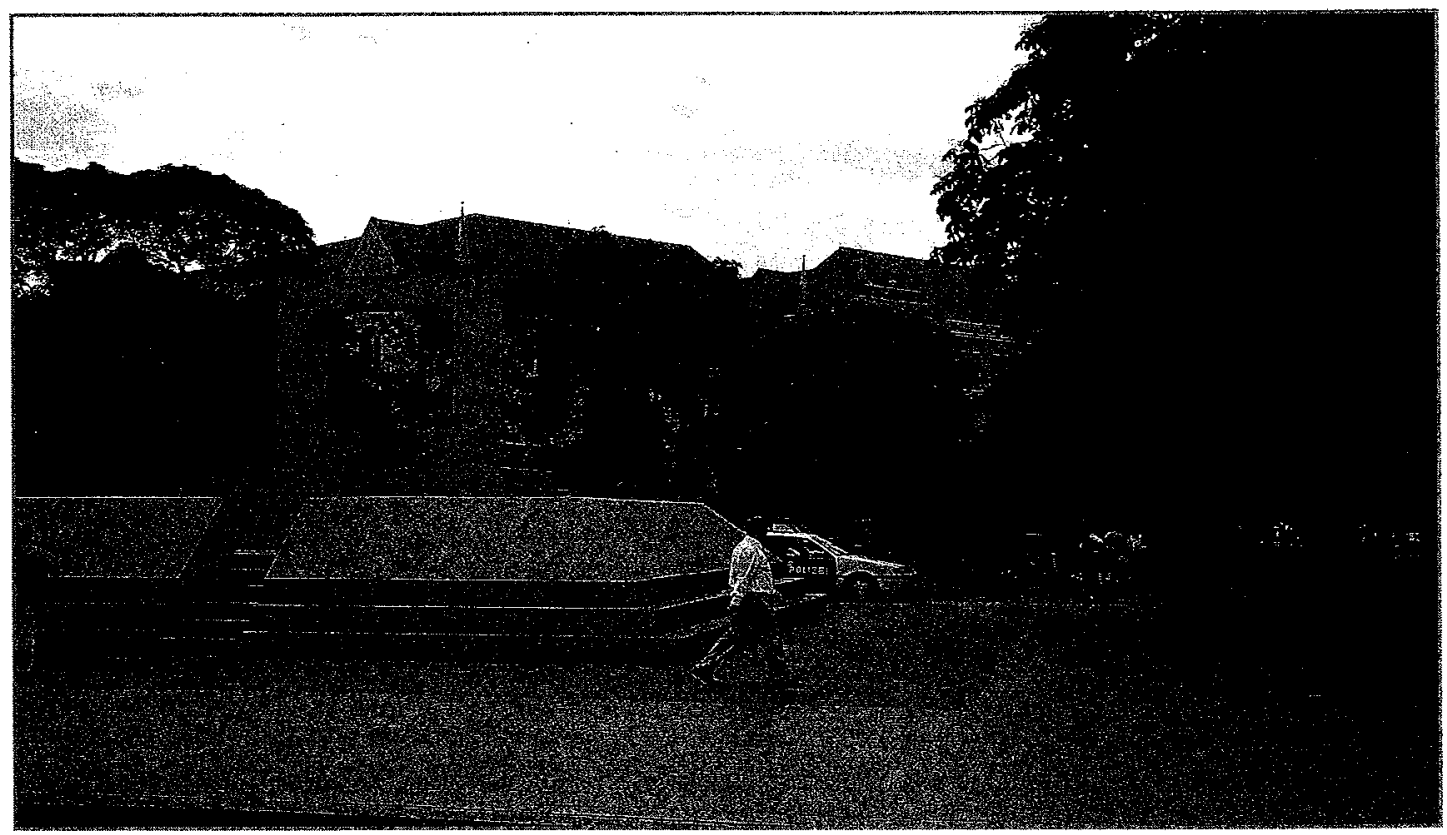


local Jewish victims of the Nazis. ${ }^{3}$ Earlier this year, I visited the memorial, located in the centre of the city, opposite the opera house. While my attention was focussed on the monument, I registered half a dozen men and women who were sitting on the grass in a small park across the road. Their appearance suggested that they were what most Germans refer to as Penner, people living on the street. While I took pictures of the memorial, a squad car pulled up. Two police officers got out of the car and approached the group. It was only then that I remembered.

The appearance of the squad car jolted a memory which was inscribed on

Hannover's holocaust memorial but which may otherwise have remained mute. 'The true image of the past flits by,' Walter Benjamin writes. 'The past can be seized only as an image which flashes up at the instant when it can be recognized and is never seen again.'4 Elsewhere Benjamin talks of the images produced by such flashes of recognition as 'dialectial images': The dialectical image is like lightning. The past must be held like an image flashing in the moment of recognition. A rescue thus - and only thus - achieved, can only be effected on that which, in the next moment, is already irretrievably lost.'s

My next example comes from Saarbrücken, capital city of the state of Saarland in southwestern Germany. The Memorial Against Racism, Mahnmal gegen Rassismus, by the artist Jochen
Gerz, is also referred to as the invisible memorial'. Between I99I and I993, Gerz and a group of students from the Saarbrücken College of Fine Arts inscribed 21 66 cobble stones taken from the public square in front of the Saarbrücken palace--which had once housed the Nazi secret police, the Gestapo-with the names of Jewish cemeteries in Germany. They then put the stones back with the inscribed side facing down. The square now 'remembers' 2146 sites, but those crossing the open space will neither know which of the 8000 cobble stones used to pave the square have an inscription nor will they be able to read the inscriptions. The project began without the consent of Saarbrücken's city council; Gerz and his students secretly replaced the first few stones at night.

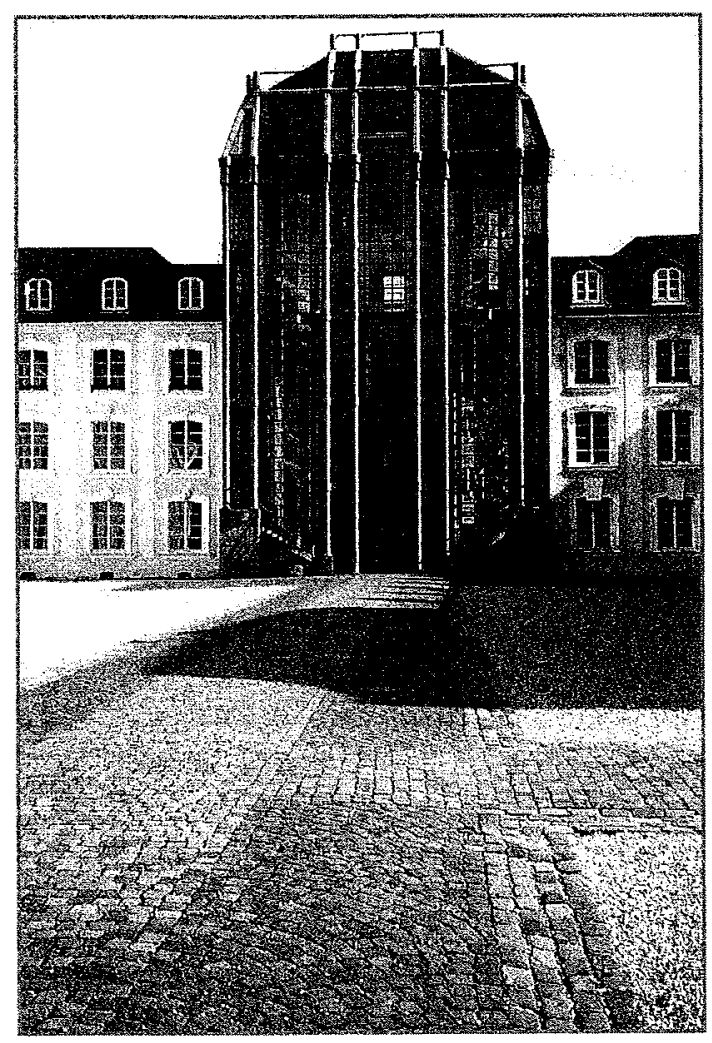


When the proposal for the Memorial Against Racism was made public, a lively debate ensued about whether or not the project should be realized. As in the case of the Steglitz Spiegelwand, the conservative parties represented in Council voted against the project. $^{6}$

I had sought out Gerz's memorial, one of Germany's most prominent 'countermonuments' ${ }^{7}$ I was interested in the square in front of the palace only because of the inscribed cobble stones; likewise, I was interested in the place in front of the opera house in Hannover only because of the holocaust memorial. The Saarbrücken palace is situated near the river Saar on a small hill which affords a good view of the centre of the city on the other side of the river. One of the landmarks of the city, as it presents itself from the top of that hill, is a tall building with a rotating Mercedes emblem on its roof.

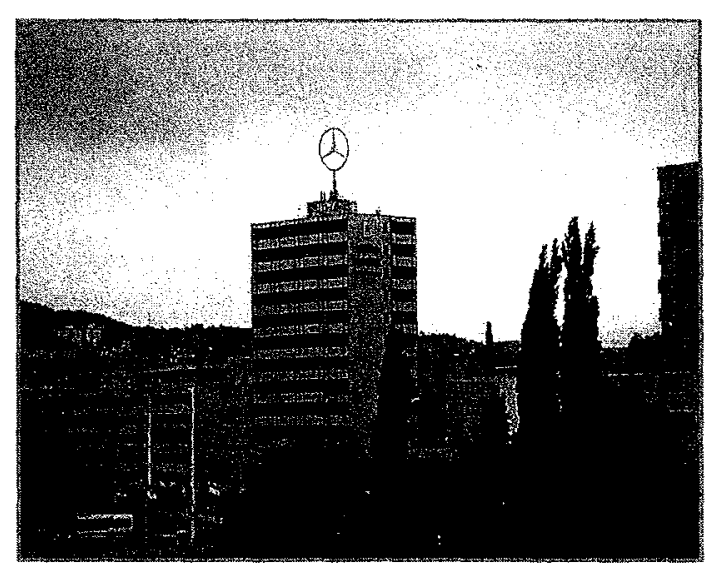

It was this view of the city, with the star of Mercedes slowly turning, which allowed me to recognize what was on the underside of the cobble stones in front of the palace. In a metaphorical sense, the stones' underside is not necessarily obscured: recognition is not paramount to the discovery of a deeper meaning. To the contrary, the search for deeper meanings often makes us blind to reflections on the surface. The stories I am telling here are phenomenological. In fact, I wish I could lighten the burden they carry by being classed as signifiers, and divest them of their meaningfulness, to make them as smooth and shiny as the mirror wall in Steglitz.

The police car heading for the homeless people in the park may have reminded me that harassment by police is one of the symptoms of ostracisation and exclusion directed against the homeless in German cities. These practices have a long tradition. ${ }^{8}$ The star of Mercedes may have reminded me of how the Daimler-Benz Company was implicated in the use of slave labour under the Nazi regime. ${ }^{9}$ There is a fundamental difference, however, between being reminded of something one knows already, and recognizing something, as if in a flash. 'It isn't that the past casts its light on the present or the present casts its light on the past: rather, an image is that in which the past and the now flash into a constellation. ${ }^{10}$

Writing about the memorialization of 'Auschwitz', is a way of writing about 'Auschwitz'. Writing about German memories of the Nazi past is a way of writing about that Nazi past. To approach 'Auschwitz' through an investigation of a collective historical consciousness and public memories of 'Auschwitz' could be 
more than an epistemological makeshift (which would allow the historian to gain a mediated view of a past too horrendous to contemplate directly). ${ }^{.1}$ To approach the past as it manifests itself in the present could be a way - and at times, the only way-of knowing the past. But there appear to be occasions when the focus on the obvious-monuments, rituals and written texts-obscures rather than illuminates the complex issues of 'Auschwitz' and of its memory. It has seemed to me that when writing about 'Auschwitz', I need to train myself to become sensitive to what is not obvious.

Surely there must be limits to how far my gaze could stray from the actual memorial I want to write about and to how useful a heightened sensibility could be? My fourth example concerns a little-known monument in the town of Celle. Celle's establishment had-and, to some extent, still has - a reputation for finding it difficult and/or unnecessary to dissociate itself from its Nazi past. For a long time, Celle has been a lawyers' town. It has accommodated one of Germany's courts of appeal (Oberlandesgericht); many of its post-war judges were dispensing 'justice' before $1945 .{ }^{12}$ Fittingly, Celle's most (in)famous son is Roland Freisler, president of the People's Tribunal, and responsible for the death of many of the Nazi's opponents. The town is also associated with, and proudly claimed, Hermann Löns (I866-I914), a poet who represented perhaps more than anybody else the sentiments of the Nazi Party's reactionary rural constituency in the north of Germany.

At the beginning of April I945, as part of a frenzied attempt to move all prisoners held in concentration camps away from the approaching Allies, the SS disbanded several satellite camps of Neuengamme and Buchenwald in the south of Lower Saxony. ${ }^{13}$ The prisoners were made to board cattle trains which were supposed to deliver them to Bergen-Belsen, a concentration camp some one hundred kilometres further north, not far from Celle. On 8 April the train arrived in Celle and was parked at the freight terminal, where the engine was to be changed. In the afternoon of 8 April, three American bomber squadrons attacked Celle's rail facilities. The train with the prisoners was hit; many of the prisoners died in the raid. The majority of the survivors tried to flee both the scene of destruction and their guards. Members of the SS, police and army then combined to recapture or kill the escapees. The security forces were assisted by members of the public, 'ordinary Germans', to use a term made famous by Daniel Goldhagen's Hitler's Willing Executioners. ${ }^{\mathrm{I} 4}$ Jointly they engaged in what became known as the 'Celler Hasenjagd', the Celle hare hunt, the hunting down of the survivors of the air raid. The 'Hasenjagd' extended until Io April. Two days later, British troops met no resistance when they occupied the town. The bombing raid on 8 April resulted in the only casualties Celle's civilian 
population suffered during the war, and in the only substantial damage to the town itself.

During the so-called 'Celle massacre trial' in $1947-48$, a British military court convicted some of the perpetrators of the atrocities of 8, 9 and io April ig45. As far as the overwhelming majority of Celle's citizens was concerned, the events had thus sufficiently been dealt with. They became part of history, albeit a history hidden from public view. ${ }^{15}$ Rather than thinking of themselves as victimizers, people in and around Celle remembered April I945 as a time when they had become victims - targetted first by Allied bombers, and then harassed by former forced labourers and by prisoners liberated at Bergen-Belsen. ${ }^{6}$

The events of April 1945 were first mentioned again publicly in a book published in 1982 , whose authors were highly critical of the apparent longevity of Celle's Nazi past. ${ }^{17}$ In 1983 , the dead of April I 945 were commemorated publicly in a ceremony organized by trade unionists at Celle's main cemetery, where many of the victims of the 'Hasenjagd' were buried. On the occasion of the foth anniversary of the bombing raid, in 1985 , Celle's daily, Cellesche Zeitung, published a detailed account of the events. ${ }^{18}$ That same year, Celle residents aligned with the union movement and the left again commemorated the victims of the 'Hasenjagd' in a ceremony at the cemetery.9 Eventually, in I 989 , the city council's Standing Committee for Cultural
Affairs decided to hold an open competition for a memorial to commemorate the victims of April $1945 .{ }^{20}$ The memorial was to be located in a park, the so-called Triftanlagen, halfway between the town centre and the railway station.

Of $28 \mathrm{I}$ models submitted for this competition, the judges chose that of Johnny Lucius. ${ }^{21}$ Lucius's memorial consists of a beech tree which is enclosed by a square horizontal frame of steel, set in a square bed of gravel.

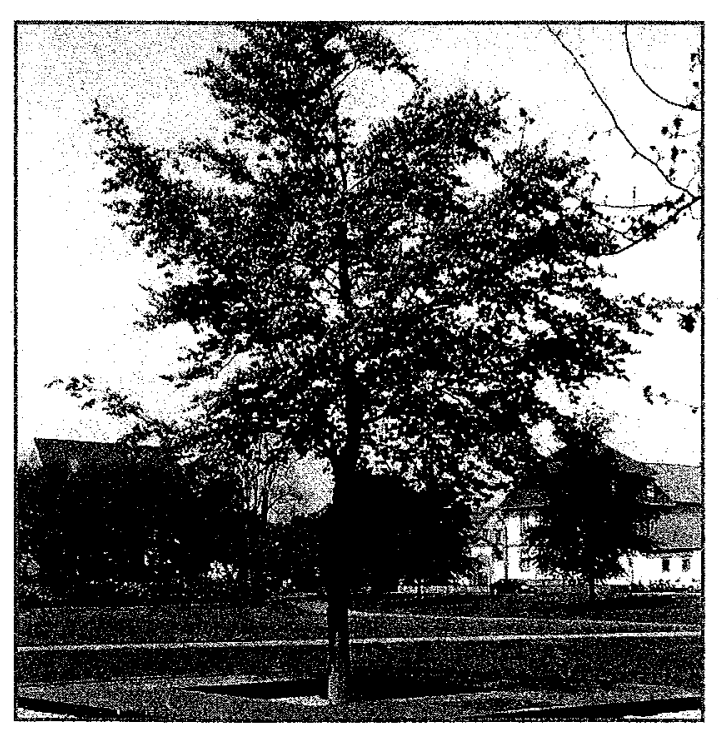

The terms of the competition had stipulated that a lengthy prescribed text about the events which occurred between 8 and Io April 1945, be integrated into the memorial. Lucius used raised letters to write the text on one side of the steel frame. The work 'evidences a great earnestness and a desire for peace,' said Dieter Ronte, director of a museum of modern art in Hannover and chairman of the committee adjudicating the competition in I990. ${ }^{22}$ The memorial was 
unveiled on 7 April 1992. Celle's mayor, the chief rabbi of Lower Saxony, the local head of the Lutheran Church, and a Polish survivor made speeches. The picture accompanying the newspaper article which reported the ceremony depicts a total of about thirty onlookers. ${ }^{23}$

In the context of the park, the memorial is rather inconspicuous. Children mistake it for a sandbox. As the steel frame and the bed of gravel are slightly raised, anybody walking on the path closest to the memorial would fail to become aware of the text which is part of it. Of all the models submitted in I990, Johnny Lucius's was perhaps the least offensive. Only on one other occasion so far, in $\mathbf{1 9 9 5}$, has the city of Celle organized a ceremony at the memorial to commemorate the anniversary of the bombing raid and subsequent killings. ${ }^{24}$ The monument has thus become a memorial to the town's unwillingness to confront the past, as much as to the past itself.

The memorial's nondescript appearance would perhaps not provoke reflections on

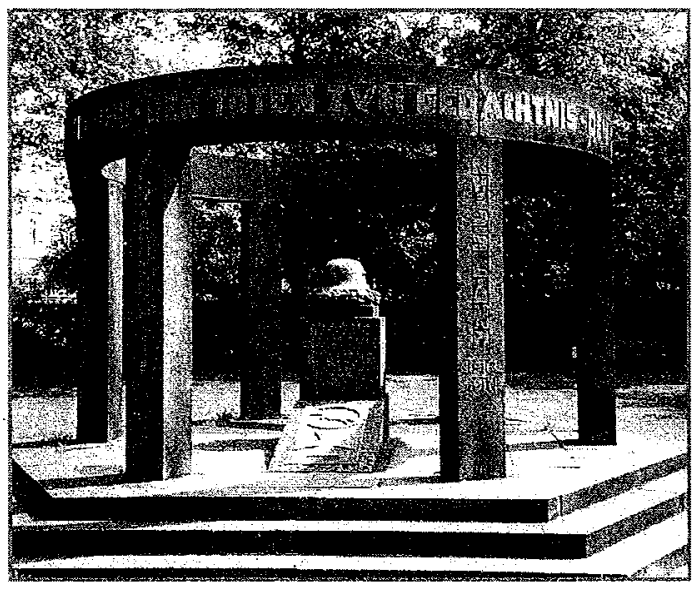

Celle's relationship to its past if it was not for another monument in the same park, for the dead of World War I. Unlike other designs, which tried to address and challenge the war memorial's presence, Lucius's design appears to be deliberately deferential, as if to respect the seniority of the earlier monument. For me, the war memorial's proximity sparked an act of remembering which-according to those initiating the memorial--Lucius's tree alone was supposed to have elicited.

I do not know what I expected to find when I headed away from the memorial, to Celle's central railway station. In a diffuse way, I was drawn to the tracks and

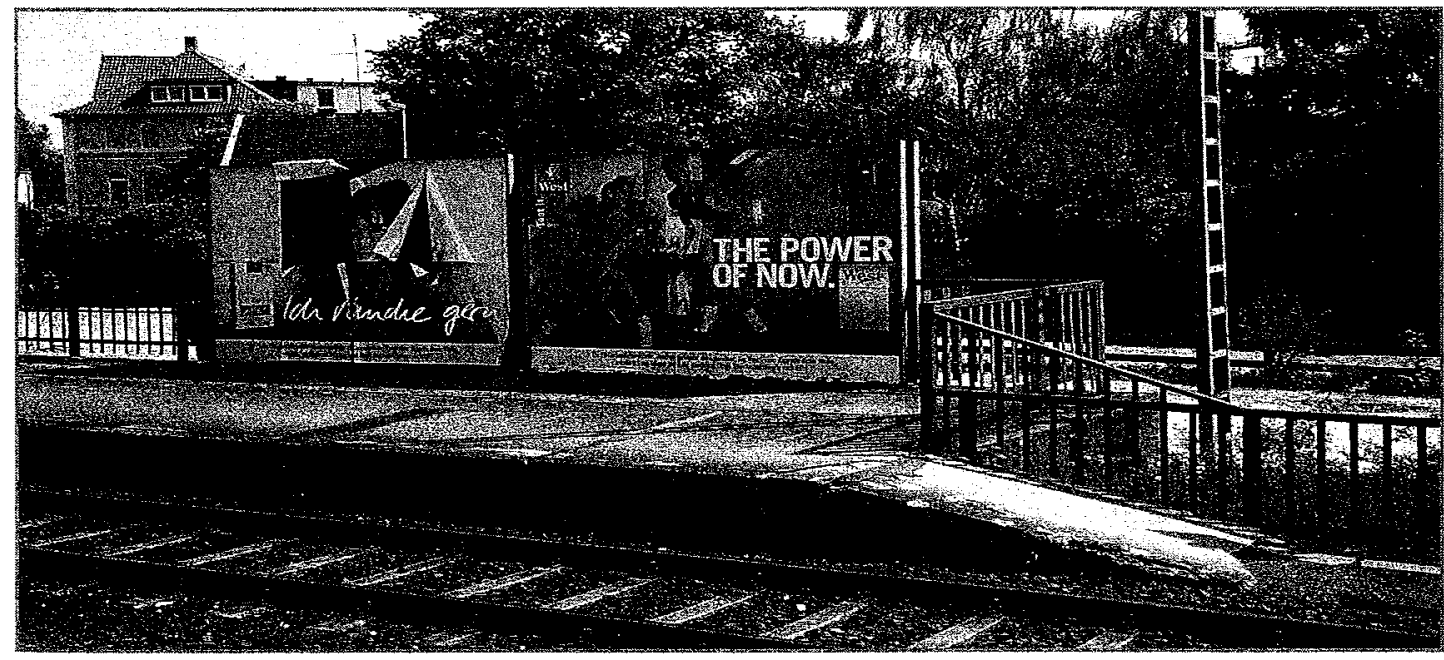


trains and platforms: I was, however, aware that the train carrying the prisoners had been parked at the freight terminal rather than at the railway station which I now sought out. The past appeared seemingly from nowhere, propelled by a force disguised as the power of the now.

Celle's claim to fame are its half-timbered houses. They would be less remarkable if it was not for the fact that the historic town centres of most other German towns fell victim to Allied bombing raids. 'Celle: die romantische Fachwerkstadt', 'Celle: romantic town of half-timbered houses', the sign at the railway station reads.

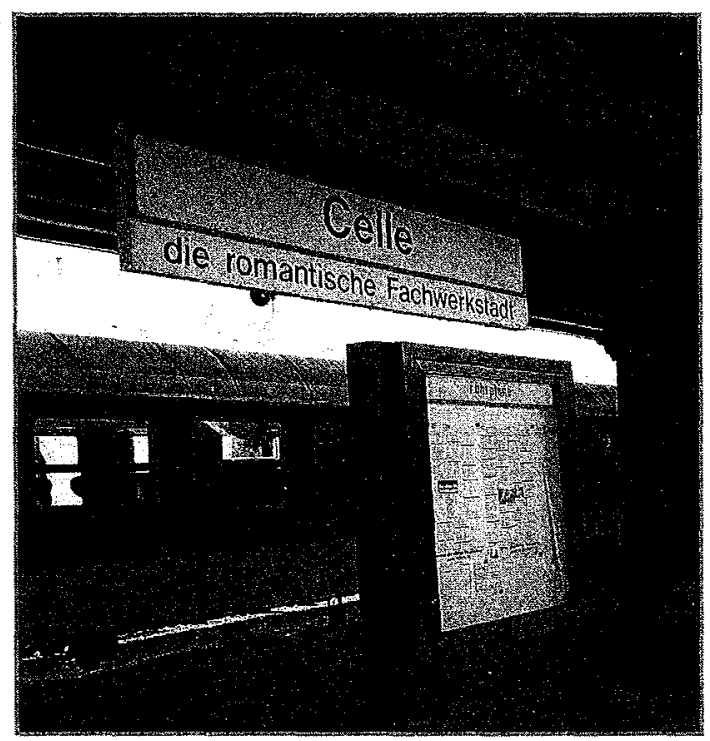

Celle itself, visitors are made to believe, is tangible evidence of a distant past. In this romantic town, there is seemingly no need to forget or remember the Nazi years-as if they had not happened yet. The town has largely sealed itself off from public debates about issues of remembrance and forgetting-not by rejecting them but by pretending that they cannot even be imagined.
In Celle's railway station, billboards warn us against littering: In 1997, Celle presented itself as a clean city. It has supposedly shed the image of a town with lots of skeletons dating from its Nazi past in its closet. The city maintains a small museum in the local synagogue, which survived the Reichskristallnacht pogrom, and is proud of its Jewish heritage- to the extent of granting Jews from Hannover the right to use the synagogue, but not to the extent of inviting Jews from the former Soviet Union to settle in Celle. ${ }^{25}$ Instead of continuing to pride itself on its links with Hermann Löns, Celle now honours Arno Schmidt (I914-I979), whose avant-garde writings could not be more antithetical to Löns's: in I994, the square in front of the Celle Public Library was named after Schmidt.

I am concerned about contexts which are easily left out of our field of vision when we focus on memorials: homeless people in a park in Hannover, the star of Mercedes on the roof of a tall building in the centre of Saarbrücken, and signs and billboards at Celle's central railway station. They help me to remember the subject matter of the actual memorials: of the holocaust memorial in front of Hannover's opera house, of the Memorial Against Racism in front of the Saarbrücken palace, and of the memorial to commemorate the prisoners killed in Celle in April r945. My approach is perhaps reminiscent of that of Jochen Gerz in his earlier project, EXIT, an exhibition of photographs of various signs he found in the Dachau concentration 
camp memorial ('Please do not write on the walls', 'Please do not damage the exhibits', 'Not recommended for visitors below the age of r 3 ', 'Exit', etc.). ${ }^{26}$

So far I have talked about spatial digressions from a memorial's immediate context. Before moving on to a digression which is also temporal, let me say a few words about the relevance of toying with supposedly irrelevant contexts. For the past three years, Germans have debated the question of whether or not Germany should have a national holocaust memorial in Berlin, and if so, what kind of memorial would be appropriate. Opponents of the memorial have pointed out that as long as the federal government is not willing to guarantee sufficient funding for the existing memorials at authentic sites, it would be hypocritical to spend $I_{5}$ million mark on a new memorial which is situated far from these authentic sites. Authentic sites are sites of persecution such as concentration camps or collection points for deportations to ghettos and camps in Eastern Europe. Memorials are sometimes placed in close relation to them: the Memorial against Racism is situated opposite Saarbrücken's former Gestapo headquarters. The Spiegelwand in Steglitz was intended to be also a reminder of a former synagogue which since $199^{2}$ has been hidden behind a new apartment block facing Hermann-Ehlers-Platz. Neither Celle's railway station nor the park where the monument to commemorate the victims of the 'Hasenjagd' stands, would be considered particularly authentic, although it was argued that the latter is more authentic than other potential sites in Celle. ${ }^{27}$ Whether or not a site is authentic can be a hotly contested issue. As the Steglitz example demonstrates, developers tend to have particularly narrow views about which area could be classified as an authentic site.

By establishing seemingly random connections between a memorial and a logo, or between a memorial and a billboard, I am downplaying the importance of the site of the memorial. Flashes of recognition are not predicated on the whiff of authenticity supposedly emanated by a site, although in some cases a site's aura could trigger such flashes. The past is never already there--neither on Hermann-Ehlers-Platz in Berlin nor in front of the Saarbrücken palace.

Potentially, however, the past lurks behind every corner-if, and only if, it is recognized. Potentially, all of Germany is an authentic site.

In my last example, I will briefly recount the history-or what James Young calls the 'biography' 28 _ of a memorial but also tell an incidental history, thereby aiming to construct a seemingly irrelevant but parallel past. I am from Hildesheim, a city of about roo,0oo inhabitants some 25 kilometres south of Hannover. Hildesheim's townscape is dominated by its churches, and so is much of its political and social life. Hildesheim has been a Catholic enclave in the protestant North of Germany, although since 1945 , with the 
city accommodating many refugees,

Hildesheim's Catholics have been

outnumbered by its Protestants. Growing up in Hildeheim, I learned to associate my home town with its churches. At some stage during my high school years, I found out that Hildesheim also had had a synagogue. I may have learned of its former existence from a memorial stone at Lappenberg, where the synagogue had stood until it was burned down on the night of 9 November 1938 . Then, I read the memorial (which is depicted on the cover of this issue of Humanities Research) in the light of what I knew about the nation-wide pogrom in November $193^{8}$. I did not understand, or even imagine, it in the context of a local German-Jewish history-the church steeples of Hildesheim seemed to be too imposing to allow for anything but a fleeting and marginal Jewish episode in my town. Thus the memorial appeared as a reference to events which had happened elsewhere. ${ }^{29}$

By the time I returned to Hildesheim to explore the way the Nazi past has been memorialized in Germany, a second monument had been erected at Lappenberg to draw the attention of passers-by to the burning of the synagogue.

Its location and size are more conspicuous than that of the old memorial stone, which I had known as a teenager. The new monument is a cube of red marble, 2 by 2 by 2.3 metres; which sits on a bronze base. A bronze model of the temple of Jerusalem, carried by four lions, rests on top of the cube. Motifs from Jewish history are depicted in bronze or marble bas-relief on the four sides of the cube. One of the

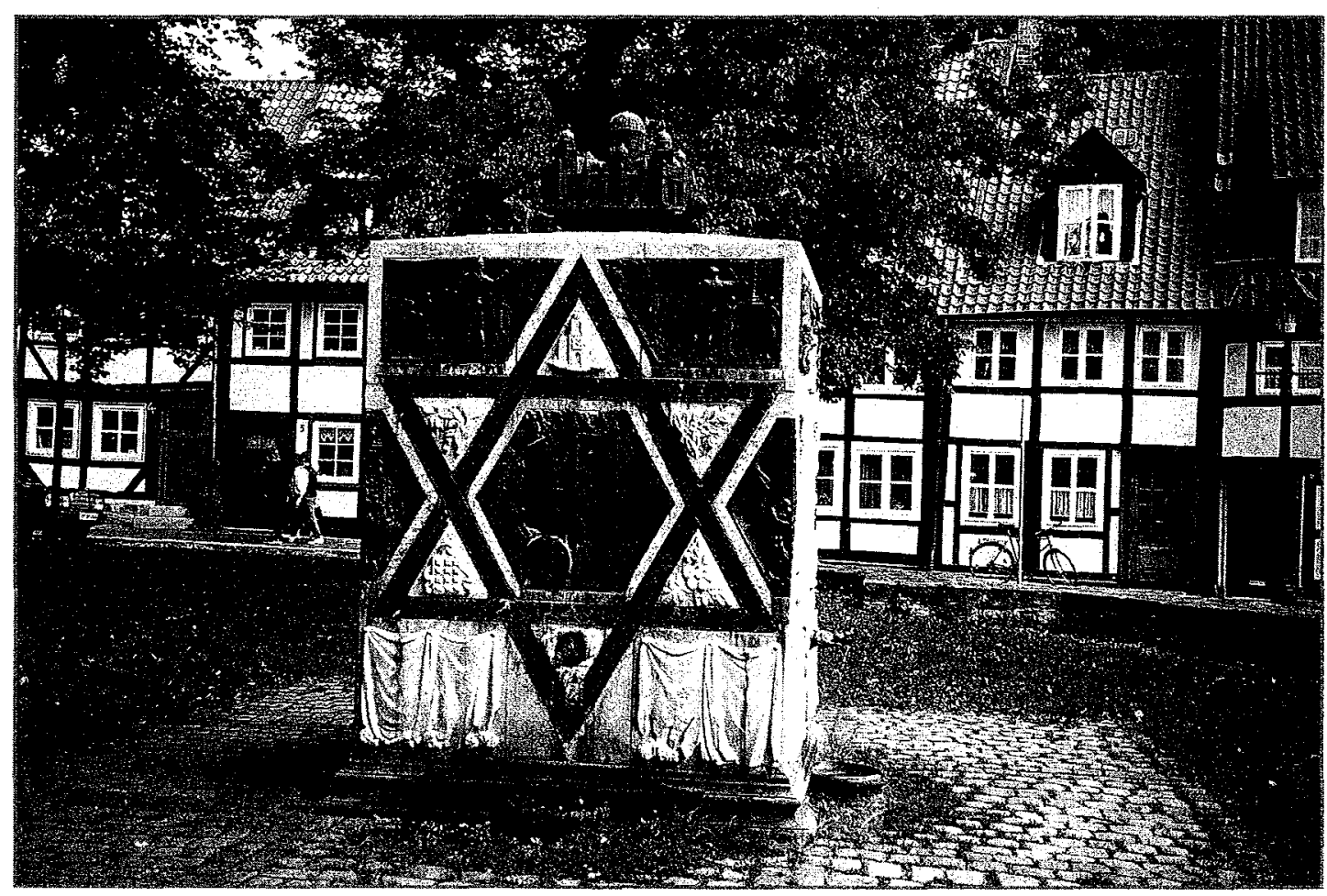


sides depicts scenes related to the persecution of Jews: the imprisonment of the Jews by Nebuchadnezzar in Babylon, the conquest of Jerusalem by the Romans, the burning of Hildesheim's synagogue on the night of 9 November 1938 , the deportation of Jews from the Warsaw ghetto, and the killing of a Jewish mother and her child by a member of the SS. The last three bas-reliefs are based on wellknown photographs. The image of the burning synagogue has a smaller inset which shows Hildesheim on fire as a result of an allied bombing raid on 22 March 1945. A low wall marks some of the foundations of the synagogue.

The decision to fund the first memorial was made at a council meeting on 14 March 1947. According to the minutes, 'Council voted unanimously to provide $3^{600}$ Mark in the next budget for a memorial stone at the site of the synagogue ... A motion by Alderman Hanne to involve the public by way of a subscription was defeated to one vote. ' ${ }^{30}$ The monument's inscription reads, in Hebrew, German and English, "This was the place of the synagogue destroyed by sacrilegious hands the 9 th of November I938.' By neither naming the owners of those hands, nor mentioning the wider context of the $193^{8}$ pogrom, the aldermen had chosen a conventional solution ${ }^{31}$ The open space created when the synagogue was burnt down was made into a small park and planted with trees.

Alderman Louis Hanne was a Social Democrat and thus likely to have been an opponent of the Nazi regime. I assume that his proposal was rejected because his colleagues did not think that a public subscription would yield the funds required for the monument. The other aldermen would have been right to be more skeptical about the enthusiasm for such a memorial among Hildesheim's citizens. A newspaper report about the unveiling of the monument on 23 February 1948 notes a 'good turnout of representatives of the churches, political parties and trade unions but the nearly total absence of the population of Hildesheim'. ${ }^{32}$

The synagogue was built in I 849 in the part of Hildesheim referred to as the Neustadt, 'new town'.

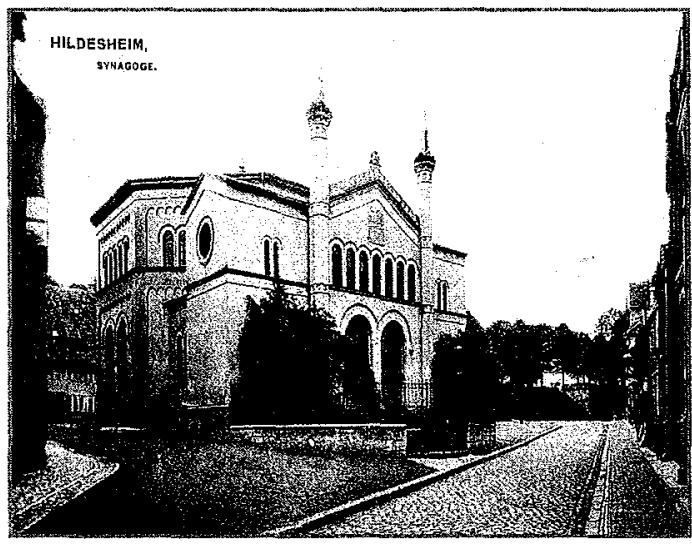

Then, most of the houses in this part of Hildesheim dated from the sixteenth and seventeenth centuries; the Neustadt was 'new' in relation to the older town centre. The half-timbered houses in Hildesheim's Neustadt were considered not nearly as attractive as those in the older part of the town, which gave Hildesheim the reputation of being the Nuremberg of the North'. The gem among Hildesheim's 
secular buildings was the

Knochenhaueramtshaus, a seven-storey

half-timbered house facing the town

square. 33 It had been completed in $5^{2} 9$

and was initially owned and occupied by

the butchers guild. In I 884 a fire destroyed

the upper storeys of the building. Council

did not hesitate to allocate the sizeable

sum of $3^{0,000}$ mark for its restoration.

Like most of the 'old' Hildesheim, the

Knochenhaueramtshaus, then held to be

the most beautiful half-timbered building

in Germany, if not in the world, fell victim

to the bombing raid seven weeks before

the end of World War II (and two weeks

before Hildesheim was occupied by the

American army). A pile of ash was all that remained of the famous building.

After the war, various groups of citizens

lobbied for the reconstruction of the

Knochenhaueramtshaus. While the city

council was not openly opposed to such a plan, it was obvious that with seventy per

cent of Hildesheim in ruins, there were

more pressing needs on the council's

agenda. Rather than deciding against a

reconstruction of the

Knochenhaueramtshaus, the majority of

aldermen voted in favour of an

enlargement of the town square, partly in

order to provide additional parking space.

This solution, which implicitely prevented

the reconstruction of Hildesheim's

erstwhile symbol, was also approved by a

majority of voters in a referendum in 1953.

Ten years after the referendum, a seven-

storey hotel was erected where once the

Knochenhaueramtshaus had stood.
Eighteen years after the bombing raid, Hildesheim's new town square was finally complete. While most of the old secular buildings in the centre of Hildesheim had gone for good, its main churches-also heavily damaged during the war-had been restored to their former glory. By r 963 , samples of bland post-war architecture constrasted sharply with the imposing symbols of the Catholic and Prostestant presence.

While demands for the reconstruction of the Knochenhaueramtshaus had been subdued, particularly after the 953 referendum, they never ceased. In $197^{\circ}$, with the twenty-fifth anniversary of Hildesheim's destruction approaching, a group of fifteen local citizens, most of them journalists, commenced a new campaign for the reconstruction of the building which had once contributed so prominently to Hildesheim's fame. This time both the city's administration and the majority of council were favourably disposed to the idea, which also had considerable popular support. All parties concerned agreed, however, that for obvious reasons the

Knochenhaueramtshaus could not be rebuilt on its former site.

Thirteen years later, plans to reconstruct the Knochenhaueramtshaus no longer sounded utopian when Council decided to return the town square to its original size. The vote had been preceded by discussions about the reconstruction of the facade of another historical building 
facing the old town square, the

Wedekindhaus. As it became apparent that this project was feasible, not the least

because Hildesheim's citizens

demonstrated their support by donating more than 6oo,ooo mark for the reconstruction of the facade, the reconstruction of the entire former square suddenly appeared to be an option. The conservative majority of Council voted in favour of funding the reconstruction of the Wedekind facade. One of those speaking in favour of this project was the city treasurer, Hermann Siemer. On 2 March 1983 he was quoted as saying: "The Wedekind facade has to offer more than if the funds went into social projects. Building the Wedekind facade is in fact a measure of social policy. You have to see these things in economic terms. ${ }^{34}$

While Hildesheim's old centre was nearly completely wiped out in the Allied bombing raid of 22 March 1945, much of the Neustadt, including the immediate neighbourhood of the synagogue, had been spared. The site of the former synagogue, the so-called Lappenberginsel, was a small park of triangular shape flanked by two narrow streets with small half-timbered houses on two sides and a large red-brick building from the late nineteenth century at the third. In the first twenty-five years after the war, little attention was paid to the old houses, which date from the sixteenth century. Many of them were run down and lacked basic sanitation. They were often inhabited by poor and old people. At one stage it looked like some of these houses would be pulled down in order to widen the existing streets and provide room for new houses. But from the I97os, the Neustadt was slowly gentrified. Public opinion demanded to save what was left of the old Hildesheim. Council was under some pressure to redevelop the Lappenberg neighbourhood while at the same time preserving the buildings dating from Hildesheim's early modern past. In the I97os, however, neither the foundations of the synagogue nor the memorial featured in public debates about what to do with the Lappenberg. ${ }^{35}$

Only since 1978 have ceremonies at the site of the former synagogue marked the anniversaries of the pogrom of 9 November $193^{8}$. The 1983 commemoration was attended by the mayor of Hildesheim, the deputy town clerk, and a group of students.$^{36} \mathrm{~A}$ few months later, the idea to commission a larger memorial was born. The old memorial was now considered too small. The chairman of the council's Standing Committee for Town Planning and Construction described it as 'a pathetic and pitiful stone' ('ein mickriger und jämmerlicher Stein'). ${ }^{37}$ And, as early as 1984, some local politicians were apparently concerned about the need adequately to commemorate the fiftieth anniversary of the pogrom.

Funding for the new memorial was provided by a trust belonging to the city of Hildesheim, the Weinhagen Foundation..$^{8}$ 
The board of directors and board of trustees of the Foundation were largely identical with Hildesheim's most senior public servants and key members of the city council. The town clerk and the city treasurer were ex-officio managing directors of the trust. Treasurer Hermann Siemer, then a man in his early forties, who had studied philosophy and theology before embarking on a career as a public servant, became the driving force behind the new monument:

The Foundation's board of trustees decided very early on that they wanted a representative and conspicuous monument which could be easily 'read' by passers-by. They approached several artists who had worked in Hildesheim on previous occasions. Of the four designs submitted to the Foundation, the board of trustees chose that of Elmar Hillebrand, an artist and professor at the College of Arts in Cologne, who proposed a cube with motifs from Biblical History. Hillebrand then agreed to involve the three artists whose designs had been rejected. The four of them drew lots and each designed one side of the cube, with Hillebrand also providing the overall design and the model of Jerusalem at the top. Each side of the cube has a theme: the Jews as the Chosen People; Jewish Law; Jewish cult; and persecution. A series of motifs represents each theme. To accommodate several different motifs as well as texts, a star of David divides each side into thirteen segments.
The memorial cube alone cost 70o, ooo mark; the total costs of the memorial amounted to I.I million mark. ${ }^{39}$ According to Hermann Siemer, the memorial was funded by the Weinhagen Foundation rather than directly through the city's budget because it could have proven difficult to elicit the support of the majority of Council for the project. Hildesheim's politicians were not enthusiastically in favour of a new memorial, Siemer explained to me, but neither were they openly against the proposal because

$$
\begin{aligned}
& \text { people do not like to say things that can be } \\
& \text { interpreted as antisemitic. Now if you } \\
& \text { propose to build a Jewish memorial } \\
& \text { [Judendenkmal], then the local politician } \\
& \text { won't say, 'I'm against it'. Because then he } \\
& \text { would be shown in a bad light. Therefore he } \\
& \text { needs to oppose [the project] cautiously.9 }
\end{aligned}
$$

While the city's politicians were not openly against a new memorial as such, its erection was by no means uncontroversial. Before the space where the synagogue had once stood was redesigned, the city commissioned an engineer to excavate the foundations of the synagogue..$^{i}$ After reviewing the results of the excavation, the Chief Curator of Monuments in Lower Saxony asked: Why should there be a memorial here-after all the whole area is already a memorial?'42

As in many similar cases in the Federal Republic of Germany, the initiative to commemorate the victims of Nazi Germany was taken by the descendants of 
the victimisers rather than by survivors or the relatives of victims. While the (nonJewish) artists sought the advice of a Jewish scholar, Pinchas Lapide, who has written several books which argue for an acknowledgment of Christianity's Jewish heritage, 'there was no Jew among those who designed or realized the monument, nor among those who had the idea to build the monument', Hermann Siemer admitted.

There weren't any Jewish participants, not even indirectly. My efforts to get the Jews in Germany interested, more or less failed. I rang the chairman of the Central Council [of Jews]...but I could not deduce any real interest from this conversation. This is something I regretted beeause it dampens your spirits a bit. You think, if there was any interest at all, then those who suffered [under Nazi rule], or whose parents or brothers and sisters suffered, they would support [such a project]. ${ }^{43}$

Apparently, today's non-Jewish Germans need the Jewish victims and survivors of Nazi Germany to legitimate their peculiar ways of atoning for the crimes committed or condoned by their parents and grandparents.

Those responsible for commissioning the memorial made an effort to obtain a public consensus among Hildesheim's citizens before the artists embarked on the actual construction of the monument. A life-size model of the memorial was exhibited at the designated site in March 1987 , partly to alleviate fears about the memorial's size.44 The comparatively modest public dissent regarding the memorial, which had been most pronounced when the foundations of the synagogue were excavated in November 1987 , dissipated in the couple of months preceding the unveiling of the monument. Yet the authorities remained wary of opponents of the project. Once completed the cube was encased in a large wooden box for fear that right-wing extremists would damage it before its official unveiling. ${ }^{45}$ As with similar memorials in other German cities, the discussion about the form of the memorial had been influenced by anticipations of its defacement. (From the perspective of anxious politicians and administrators, Gerz's Mahnmal gegen Rassismus should be the perfect memorial, its defilement seemingly impossible..$^{6}$ )

The memorial was officially handed over to the city of Hildesheim and its citizens in a ceremony on 9 November 1988 . There were speeches by the mayor, by Hermann Siemer (representing the Weinhagen Foundation), by two Jewish survivors who were then living in the United States, by a non-Jewish writer who described his witnessing the pogrom in two other German cities, and by a representative of the Ecumenical Judaeo-Christian Association, a group of Hildesheim Christians who have been particularly interested in the Jewish origins of Christianity.47

Whereas the controversies about whether or not this particular memorial should be built, had either not been carried out in 
public, or had been rather subdued, the ceremony on 9 November 1988 was followed by a heated and very public debate. This was due to a passage in Siemer's speech:

Auschwitz begins or can begin everywhere, where children are mistreated or just neglected. Auschwitz begins in those laboratories, where experiments are made with human embryos, allegedly in the name of progress. And Auschwitz also begins here, may God have mercy on us, where we have come to an agreement that no human being has the unconditional right to birth and life. Auschwitz didn't first begin with Auschwitz and Auschwitz need not end there.

Auschwitz begins in our hearts..$^{48}$

Siemer had made an unmistakable reference to the West German abortion laws, which permit abortions up to the third month of pregnancy under certain, closely defined conditions. The debate about these laws, which had been liberalized in the r97os, has divided Germans for decades. Conservative politicians, who have been backed by the Catholic Church, had opposed any liberalization of the old, more restrictive, laws and have indeed demanded that abortion should again be made illegal, whereas feminists have denied Parliament's right to legislate women's bodies.

The efforts of Hildesheim's citizens to commemorate Jewish victims cannot be seen in isolation from the post-war history of Jews in Hildesheim. In fact the peculiarly Christian appearance of the memorial and of the commemorative ceremonies conducted at the site until recently were only possible because of the successful eradication of a Jewish presence in Hildesheim more than fifty years ago. After the war, some Jewish survivors returned to Hildesheim. But the number of Jewish citizens steadily declined. In 1957 there were still seventy Jewish families in the district of Hildesheim, and nine in the town itself; 49 by 1988 , probably only one Jew was living in Hildesheim. Now there is again a sizeable Jewish community in Hildesheim, comprised mainly of Jewish immigrants from the Ukraine and other countries which emerged from the Soviet Union.

Peter Hirschfeld is the chairman of the Jewish congregation which was founded in February 1997 in Hildesheim..$^{\circ} \mathbf{I}$ interviewed him the day after the 1997 Yom Hashoah commemoration at Lappenberg which once again had been organized by the Ecumenical JudaeoChristian Association:

I think it is appropriate to keep alive [the memory] of what has happened... If the Jews are not in a position to organize that themselves, then it's $0 . K$ for the city or the churches to take over this task ... Now that a [Jewish] congregation has been set up, we have to approach this in a fundamentally different way ... For example, there are lists of the Hildesheim Jews who perished in the concentration camps. $\left.{ }^{[5]}\right]$ So we might say: 'O.K., dear Church, please write placards with 
the victims' names, and carry them through town.' And then we meet on that day [that is, Yom Hashoah] with these placards at the memorial. So the Church is given an assignment, to demonstrate in a tangible way: 'we are standing here on behalf of those who were murdered.' Or we could put the leaders of the city or the church in prisoners' clothing and let them say: We are standing here on behalf of the Jews whom we murdered. ' 52

The $199^{8}$ Yom Hashoah and

Reichskristallnacht commemorations will probably be organized by Hildesheim's Jews rather than by the Christians from the Association. Should non-Jewish Germans insist on commemorating the pogrom in Hildesheim, then they could perhaps recall the names and deeds of local perpetrators and bystanders, rather than those of their victims.

The erection of the new memorial in 1988 became an integral part of the redevelopment of the Lappenberg. ${ }^{.33}$ The old houses were renovated. The red brick buildings were demolished and replaced by a row of two-storey houses which fit into the sixteenth-century streetscape. Plans for a widening of the existing streets were shelved; in fact, the Lappenberg became a cul-de-sac. In the iggos, however, the Lappenberg and other parts of the Neustadt are no longer considered the most obvious showcases of the old Hildesheim. In 1984 , the city of Hildesheim reacquired the block of land formerly occupied by the

Knochenhaueramtshaus. Three years later, the hotel built in 1963 was demolished, and the foundations were laid for the new Knochenhaueramtshaus. In 1989 , a restaurant opened its doors in the new building. On 22 March 1990, the citizens of Hildesheim celebrated rather than mourned as they had done on the previous forty-four anniversaries of the bombing raid which had destroyed the Knochenhaueramtshaus: the day was chosen to open the new local history museum in the reconstructed Knochenhaueramtshaus. Forty per cent of the total cost of this and of the building next door, the former $0 \approx$ ces of the bakers guild, were raised by Hildesheim's citizens and businesses.

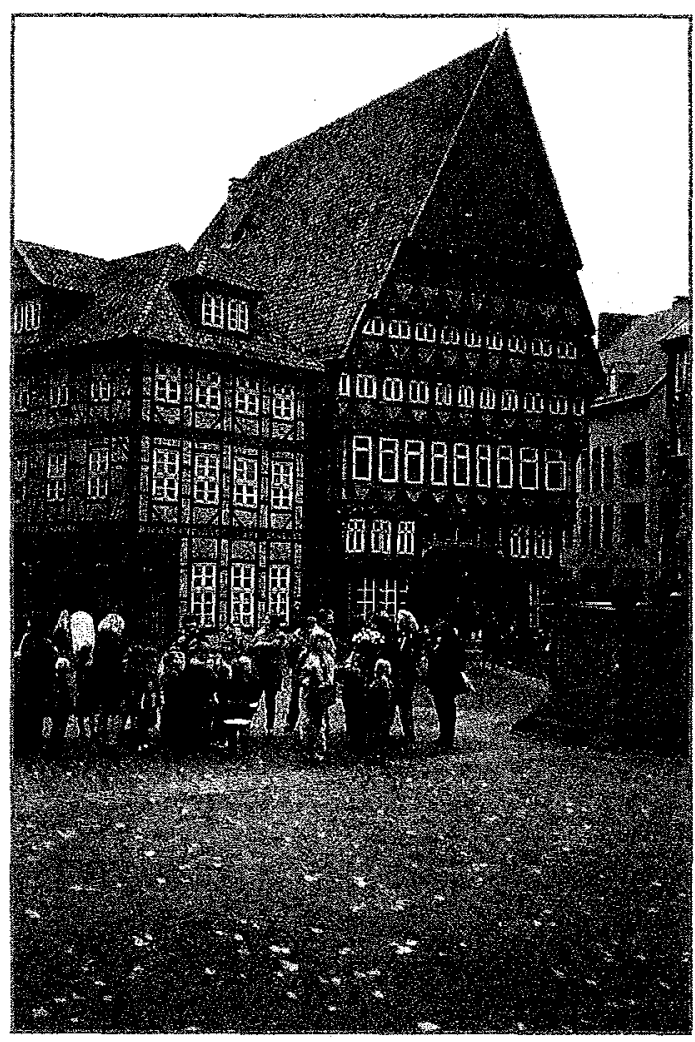

At the end of the 198 os, Hildesheim had finally recovered from the e $\Omega$ ects of war and Nazi rule-or so many of its political 
leaders suggested. The redevelopment of the market square and of the Lappenberg were projects which had the support of Hildesheim's citizens. Unlike in 1948 , many of them attended the unveiling of the memorial at Lappenberg in 1988.54 Hildesheim's citizens are proud to have undone the symbolically most important damage inflicted in the bombing raid of 22 March 1945 by rebuilding the

Knochenhaueramtshaus. And, I believe, they are also proud to have mastered (bewältigt) the Jewish aspects of Hildesheim's past.

In retrospect it seems as if the people of Hildesheim needed to make a conclusive statement about the holocaust before they could address the issue of the town's destruction by Allied bombers. Six years after the erection of the new memorial at Lappenberg, a memorial plaque dedicated to the 'victims of war and terror' was unveiled in the market square. It commemorates the raid of 22 March 1945 and is meant to express the joy of the people of Hildesheim about the reconstruction of the historic market square'.55 The first memorial in Hildesheim explicitely to commemorate the victims of the Allied bombing raid of March 1945, however, was the monument at Lappenberg: the burning city--by then long judenrein-is depicted on the side of the cube dedicated to the theme of persecution.

In lieu of a conclusion I shall return once more to the Spiegelwand in Steglitz. The image at the beginning of this essay, I suggested, is a cropped image of what I could see when standing in front of the memorial. I did not yet refer to its irrelevant context (which could be glimpsed but was not emphasized in my first image). Before doing so, I will retrace some of my steps. A memorial can, to use Robert Musil's words, '[cause] the glance to roll off, like water droplets off an oilcloth, without even pausing for a moment'. $5^{6} \mathrm{~A}$ textual reading of memorials, I am arguing, does not get us very far. The memorial as such does not remember; the person standing in front of it may, or may not, do so.

My current project, of which this essay is but a small part, has two aims: first, to grasp and portray the extent and nature of social and public memories of the Nazi past in Germany, and second, to remember that past by writing about memories of it. In order to achieve the first aim I have done interviews and listened to public discourse to the limited extent to which that has been possible for someone living in Australia. As this essay may have demonstrated, the first aim and the second aim cannot always be easily reconciled. I am not as disinterested a reporter as would be desirable if I was intent on pursuing the first goal only. In my writing I conceal and disclose information in order to surprise and disturb and provoke my audience. There are many other stories that could be told about Celle and Hildesheim. 
I contend that the parallel histories of the restoration of Hildesheim's historic market square and of the erection of a holocaust memorial, are linked. More importantly, my telling of a history incidental to the history of the new Lappenberg memorial was to divert my readers' attention from the image of the marble cube. It wás to enable them to draw connections, and to allow me to ask: what do you remember? In asking this question, I am counting on your, my readers', associative imagination. I have been explicit about links I see between the two histories. Conceiving of my role as that of a facilitator rather than a mere provider of knowledge, I have also constructed juxtapositions to provoke you to make links beyond my immediate control.

The achievement of the second aim of my project, the remembering, and eliciting of memories, is dependent on my own flashes of recognition, which I try to translate into stories that are intended to engage my audience. It may not be possible to spell out the dialectical images produced by these flashes other than by offering juxtapositions which are inspired by them. It may not be necessary for my purposes that I spell out or conjure what $I$ sense to be dialectical images. My project is nevertheless reflexive. My writing needs to shuttle back and forth between the ' $I$ ', my audience, and the people I am writing about. In doing so, it attempts to negotiate and respect incommensurabilities and thrive on differences and similarities. In its reflexivity, this second aim is necessarily autobiographical. I have been interested in the moral dimensions of writing about the colonial past in the South Pacific and of writing about the Nazi past in Germany.57 Thus I have been searching for an ethics of writing history. As Zygmunt Bauman has argued so eloquently, for such an ethics to be convincing, it can only be formulated in the first person singular..$^{8}$ By leaving the safety of the didactic 'we', the 'I' can engage a 'you', by teasing and prodding, introducing decoys and offering allusions.

This is admittedly a tenuous position.

Readers may after all choose to decline, or fail to read, the author's invitation. To use one of the examples I introduced earlier: they may stroll towards the Saarbrücken palace without paying any attention to what is inscribed on the underside of the cobble stones which were used to pave the square. And what if they did follow the invitation? What I find so fascinating about the Steglitz mirror wall is that while I can hardly look at it without also looking at myself, I can't look at the mirror without also looking at something else. This 'something else' is not necessarily the text inscribed on the mirror but could be something behind me. It is as if I was inserting my self-image into a picture that was there before I arrived (as if the mirror had absorbed its surroundings).

This 'something else' could disturb any attempt to use the mirror to recognize yourself, and your self only. My last image is not only to draw attention to the self- 
reflexive side of my project, to the blurringof boundaries between spectrum and spectator, but to make it just a little more difficult for you, to assume the position you may have presumed was alloted to you in this essay. $\propto$

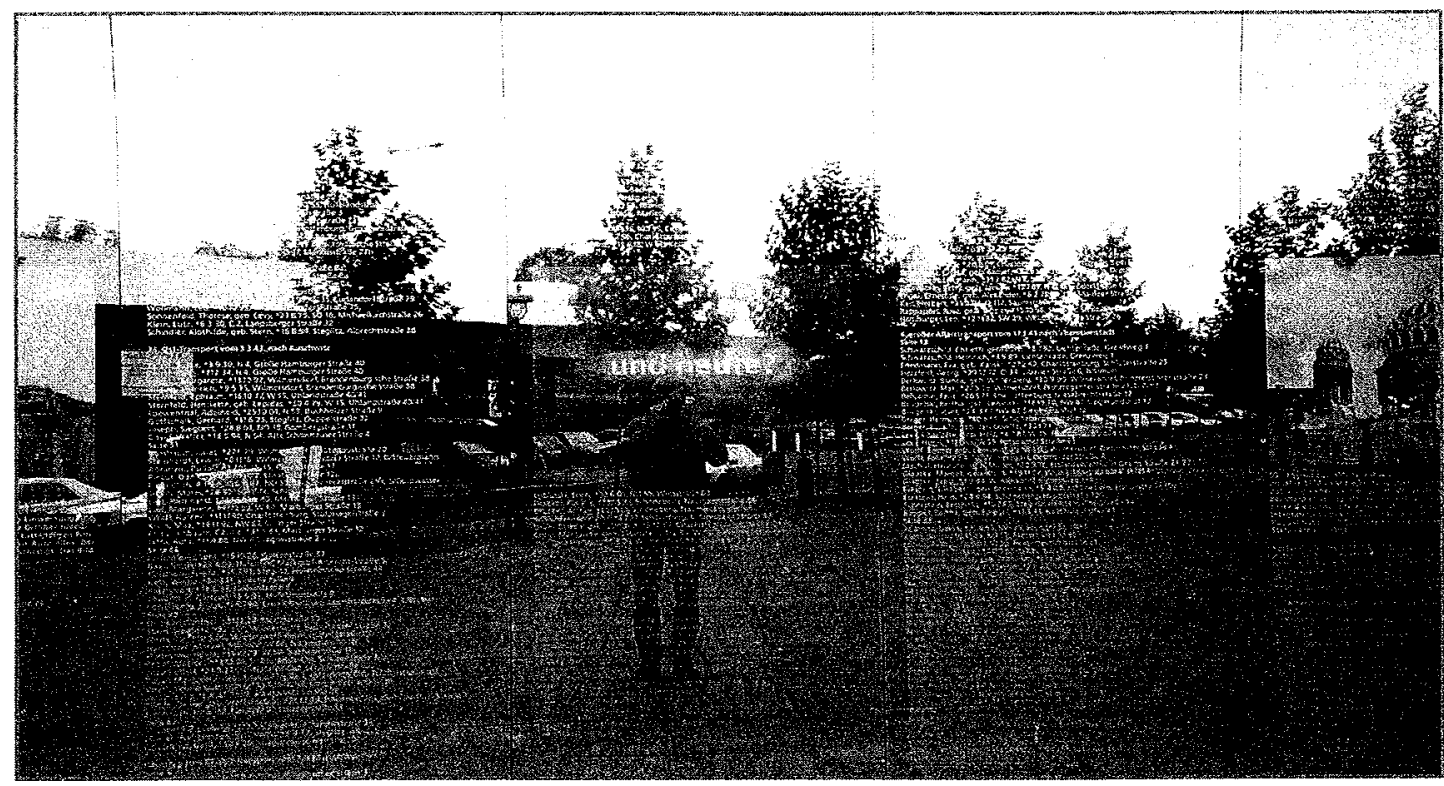

\section{NOTES:}

This essay is part of a larger project which will result in a book about the German memorialization of the Nazi past. I would like to thank the many people in Celle and Hildesheim who talked to me about their or their community's remembering of the Nazi past. The photograph of Hildesheim's synagogue is reproduced courtesy of Stadtarchiv Hildesheim (Best. $95^{2}$ Nr. $154^{-\mathrm{I}-\mathrm{I}}$ ). All other photographs are my own. Audiences at the Australian National University, University of Technology Sydney and University of California Berkeley, and two anonymous reviewers responded to earlier versions of this essay with helpful suggestions. So did Paul Magee, whose comments I gratefully acknowledge.
KLAUS NEUMANN

Klaus Neumann is a Senior Research Associate at the Centre for Cross Cultural Research

'Its history has been documented in Horst Seferens, Ein deutscher Denkmalstreit: Die Kontroverse um die Spiegelwand in BerlinSteglitz (Berlin: Edition Hentrich, I995); the memorial is by the artists Wolfgang Göschel, Joachim v. Rosenberg and Hans-Norbert Burkert, and was erected in 1995 . See also Richard Chaim Schneider, Fetisch Holocaust: Die Judenvernichtung-verdrängt und vermarktet (München: Kindler, I997), 1 $3^{2-1} 3^{8}$.

${ }^{2}$ Andreas Huyssen, Twilight Memories: Marking Time in a Culture of Amnesia (New York: Routledge, 1995), 8 .

${ }^{3}$ For the Hannover memorial, see Peter Schulze, Namen und Schicksale der jüdischen Opfer des Nationalsozialismus aus Hannover 
(Hannover: Verein zur Förderung des Wissens über jüdische Geschichte und Kultur e.V., 1995).

4 Walter Benjamin, "Theses on the philosophy of history' in Illuminations, edited by Hannah Arendt, translated by Harry Zohn (New York: Harcourt, Brace \& World, I968), 257.

${ }_{5}$ Walter Benjamin, ' $N$ ' [Theoretics of Knowledge, Theory of Progress], translated by Leigh Hafrey and Richard Sieburth, The Philosophical Forum I5:I-2 ( 1983$)$, $2 \mathrm{I}$.

${ }^{6}$ For the Memorial Against Racism, see Jochen Gerz, 2146 Steine: Mahnmal gegen Rassismus Saarbrücken (Stuttgart: Verlag Gerd Hatje, I993).

${ }_{7}^{7}$ For German countermonuments, see James E. Young, The Texture of Memory: Holocaust Memorials and Meaning (New Haven: Yale University Press, I993), 27-48; see also Peter Springer, 'Denkmal und Gegendenkmal' in Denkmal-Zeichen-Monument: Skulptur und öffentlicher Raum heute, edited by Ekkehard Mai and Gisela Schmirber (München: Prestel-Verlag, I989), 92-102.

${ }^{8}$ For such practices under the Nazi regime, see, for example, Wolfgang Ayaß, 'Vom "Pik As" ins "Kola Fu": Die Verfolgung der Bettler und Obdachlosen durch die Hamburger Sozialverwaltung' in Verachtet-verfolgtvernichtet: Zu den vergessenen Opfern des NS-Regimes, edited by Projektgruppe für die vergessenen Opfer des NS-Regimes in Hamburg e.V., and revised edition (Hamburg: VSA-Verlag, 1988), ז52-171.

${ }^{9}$ See, for example, Birgit Weitz, 'Der Einsatz von KZ-Häftlingen und jüdischen Zwangsarbeitern bei der Daimler-Benz AG (I94I-I945): Ein Überblick' in Konzentrationslager und deutsche Wirtschaft I939-1945, edited by Hermann Kaienburg (Opladen: Leske + Budrich, 1996), I69-195.

${ }^{10}$ Benjamin, 'N', 7 .
${ }^{1}$ Dan Diner, Kreisläufe: Nationalsozialismus und Gedächtnis (Berlin: Berlin Verlag, 1995), 55 .

${ }^{12}$ There is no better illustration of the continuity of the pre-1945 and post-r 945 courts in Celle than in the two relevant chapters in a book to commemorate the 25oth anniversary of the Supreme Court in Celle, which was published in 196 r: Hans Schmid, 'Erinnerungen aus den Jahren $193^{\circ}$ 1945' in 250 Jahre Oberlandesgericht Celle I7II-Ig6I, edited by Guido Schräder (Celle: Pohl, r96r), Ior-IIg; Frhr. v. Hodenberg, 'Der Aufbau der Rechtspflege nach der Niederlage von $1945^{\prime}$ in $25^{\circ}$ Jahre Oberlandesgericht Celle, I2I-I53. See also: Rainer Schröder, “... aber im Zivilrecht sind die Richter standhaft geblieben!" Die Urteile des OLG Celle aus dem Dritten Reich (Baden-Baden: Nomos Verlagsgesellschaft, 1988); Hinrich Rüping, Staatsanwälte und Parteigenossen:

Haltungen der Justiz zur nationalsozialistischen Vergangenheit zwischen r945 und rg49 im Bezirk Celle (Baden-Baden: Nomos Verlagsgesellschaft, I994).

${ }^{13}$ For the following see, Mijndert Bertram, April 1945: Der Luftangriff auf Celle und das Schicksal der KZ-Häftlinge aus Drütte (Celle: Stadt Celle, Stadtarchiv, I989).

${ }^{14}$ Daniel Jonah Goldhagen, Hitler's Willing Executioners: Ordinary Germans and the Holocaust (London: Little, Brown and Company, 1996).

${ }^{15}$ The events of April 1945 are not mentioned in the relevant chapter of a history of Celle which was first published in 1959 and republished in a revised edition in 1992: Helmut Krohn, 'Celle r945-1972' in Jürgen Ricklefs, Geschichte der Stadt Celle (Celle: Stadtarchiv Celle, 1992), 93-126. Krohn was a former town clerk of Celle. 
${ }^{16}$ See Unruhige Zeiten: Erlebnisberichte aus dem Landkreis Celle 1945-1949, edited by Rainer Schulze (München: R. Oldenbourg Verlag, r99I). Germans have tended to think of themselves as being the quintessential victims of the twentieth century: Klaus Neumann, 'Victors and victims', Generation 4:3 (1994), 30-34.

${ }^{7}$ Georg Eyring, 'In Wehr und Waffen: Celle und sein Militär' in Hinter den Fassaden: Geschichten aus einer deutschen Stadt, edited by Werner Holtfort, Norbert Kandel, Wilfried Köppen and Ulrich Vultejus (Göttingen: Steidl Verlag, 1982 ), $4^{2}$. The reference to the events in April 1945 in Eyring's article was supplied by local artist and radical amateur historian, R. W. L. E. Möller.

${ }^{18}$ 'Schicksalstage in der Heide: 8. April 1945Der Tag, an dem die Bomben fielen', Cellesche Zeitung, 6 April 1985 . Also in $\mathrm{r}_{98} 8$, the events of April 945 were mentioned in a compendium of sites of persecution and anti-fascist resistance in Lower-Saxony: Heimatgeschichtlicher Wegweiser zu Stätten des Widerstandes und der Verfolgung I933I945, volume 2: Niedersachsen I: Regierungsbezirke Braunschweig und Lüneburg, edited by Studienkreis zur Erforschung und Vermittlung der Geschichte des Widerstandes I933-1945 (Köln: Pahl-Rugenstein Verlag, 1985), 75 .

rg "Seht in jedem Menschen den Nächsten": Rund $5^{\circ}$ Celler gedachten auf dem Waldfriedhof der Bombenopfer des 8. April 1945', Cellesche Zeitung, I5 April I985.

${ }^{20}$ 'Standort Trift für Mahnmal', Cellesche Zeitung, 2 May 1989; Karin Toben, 'Wie vor den Kopf geschlagen', Süddeutsche Zeitung, 30 June / I July I 990.

${ }^{21}$ Große Ernsthaftigkeit erwächst einer sehr einfachen Form', Cellesche Zeitung, I9 December I99o; 'Damit die Unmenschlichkeit nie wieder vergessen wird', Celler Kurier, 24 February 1991. All 28I models were documented; the relevant files in Celle's municipal archives are a wonderful source for the artistic engagement with the Nazi past in the Federal Republic just prior to Reunification.

${ }^{22}$ 'Große Ernsthaftigkeit', Cellesche Zeitung, I9 December $199^{\circ}$.

${ }_{23}^{2}$ Der wachsende Baum-die Hoffnung auf ein weiteres Leben', Cellesche Zeitung, 8 April I992.

${ }_{24}^{24}$ "Tätern nicht den Triumph über Opfer lassen": Vor Krieg als Mittel zur Konfliktlösung gewarnt', Cellesche Zeitung, ro April 1995 .

${ }_{5}^{2}$ In 1996, Celle's municipal archives published a history of Jews in Celle, which, unlike a history published twenty-two years earlier, included extensive references to the local aspects of the Shoah: Juden in Celle: Biographische Skizzen aus drei Jahrhunderten, edited by Brigitte Streich (Celle: Stadtarchiv Celle, 1996); compare Zur Geschichte der Juden in Celle: Festschrift zur Wiederherstellung der Synagoge, edited by Stadt Celle (Celle: Stadt Celle, 1974).

${ }^{26}$ Jochen Gerz and Francis Lévy, EXIT: Das Dachau-Projekt (Frankfurt am Main: Verlag Roter Stern, 1978).

${ }^{27}$ The Triftanlage was the place closest to the town centre where prisoners were sighted on 8 April; the Nazi party's local headquarters were in a street adjoining the park ('Standort Trift', Cellesche Zeitung, 2 May 1989). Initially the memorial was to have been located at Celle's freight terminal, as close as possible to where the train was hit ('Gedenktafel als mahnende Erinnerung', Cellesche Zeitung, $3^{1}$ August I988). Aleida Assmann distinguishes traumatic sites fromother memorial sitesthis strikes me as a far more useful category than that of authentic sites ('Erinnerungsorte und Gedächtnislandschaften' in Erlebnis- 
Gedächtnis-Sinn: Authentische und konstruierte Erinnerung, edited by Hanno Loewy and Bernd Moltmann [Frankfurt: Campus Verlag, ı996], I3-29).

${ }^{28}$ James E. Young, The Texture of Memory: Holocaust Memorials and Meaning (New Haven: Yale University Press, I993), ix-x.

${ }^{29}$ I was not the only one who couldn't imagine Jewish life in Hildesheim: of forty-six guide books of Hildesheim that were published between 1949 and 1992, nearly half mention the burning down of the synagogue in $193^{8}$, but only two refer to aspects of Jewish life in Hildesheim other than those immediately related to the $193^{8}$ pogrom; see Barbara Thimm, Spuren des Nationalsozialismus in Hildesheim: Ein Stadtführer als Beitrag zur politischen Bildung, Diplomarbeit, Studiengang Kulturpädagogik, Universität Hildesheim (r993), ir.

$3^{\circ}$ Council minutes, session of $x_{4}$ March 1947 , Stadtarchiv Hildesheim, Best. ${ }_{0} 3$ Nr. I.

${ }^{3}$ See Ulrike Haß, 'Mahnmaltexte I945 bis 1988 : Annäherung an eine schwierige Textsorte', Dachauer Hefte 6 (I994), r35-16r.

${ }^{32}$ Hannoversche Neueste Nachrichten, 24 February i948.

33 For the campaign to reconstruct the Knochenhaueramtshaus, see Gerd Rump, 'Ein immerhin merkwürdiges Haus': Eine Dokumentation zum $25 j a ̈ h r i g e n$ Bestehen der Gesellschaft für den Wiederaufbau des Knochenhauer-Amtshauses (Hildesheim: Verlag Gebrüder Grerstenberg, I995).

34 Hermann Siemer quoted in Rump, Ein immerhin merkwürdiges Haus', 146.

${ }^{35}$ See, for example, H. Faltz, 'Strukturpflege am Lappenberg', Hildesheimer Heimatkalender (I973), $5^{8-65}$.

${ }^{36}$ 'Zerstörung der Synagoge jährt sich zum 45 . Mal', Hildesheimer Allgemeine Zeitung, io November Ig8 3 .
${ }^{37}$ Ewald Breloer, quoted in 'Klinkerbauten sollen kleineren Häusern weichen', Hildesheimer Allgemeine Zeitung, Io February 1986. For the wider context of such renewed interest in historic architecture, see Rudy J. Koshar, 'Building pasts: historic preservation and identity in twentiethcentury Germany' in Commemorations: The Politics of National Identity, edited by John R. Gillis (Princeton: Princeton University Press, I994), 226-23o.

$3^{8}$ This foundation, a brainchild of City

Treasurer, Hermann Siemer, was the result of the amalgamation of numerous small foundations, some dating back to the Middle Ages, in 1979. See Hermann Siemer, 'Die Friedrich Weinhagen Stiftung' in Stiftungen aus Vergangenheit und Gegenwart, edited by Rolf Hauer, Jürgen Rossberg und Winfrid Frhr. v. Pölnitz-Egloffstein (Tübingen: J. C. B. Mohr, I982), $405-412$.

39 Taped interview with Hermann Siemer, Hildesheim, 29 August r996; 'Das neue Denkmal ist biș zum g. November in Holzkiste verpackt', Hildesheimer Allgemeine Zeitung, $\mathrm{I}_{5}$ October 1988.

$4^{\circ}$ Taped interview with Hermann Siemer, Hildesheim, 29 August ${ }_{99} 6$. Another member of the Weinhagen Foundation's board of trustees, former deputy mayor Lore Auerbach of the Social Democratic Party, confirmed that there was much subtle opposition to the memorial (taped interview with Lore Auerbach, Hildesheim, I5 June 1997).

${ }^{4}$ See, Christian Popa, Die ehemalige Synagoge am Lappenberg-Hildesheim: Dokumentation im Auftrag der Stadt Hildesheim, betreut von Untere Denkmalschutzbehörde Hildesheim und Institut für Denkmalpflege Hannover, unpublished report ( 23 November ${ }^{8}{ }^{8} 7$ ), Stadtarchiv Hildesheim, Best. 50 4-6r Nr. I. 
$4^{2}$ Widerstrebende Meinungen zum geplanten

Lappenberg-Mahnmal', Kehrwieder, 22 November 1987 .

43 Taped interview with Hermann Siemer, Hildesheim, 29 August I996. In fact, the Department of Town Planning asked an outspoken member of Hannover's Jewish community to comment on the proposed memorial. His comments emphasized the importance of the former synagogue for the memorial ensemble. Although they were generally positive, they could not be read as a ringing endorsement of the proposal (Aram Tuvia, Die Bewertung des Planes für die Errichtung eines Denkmals am Lappenberg in Hildesheim, unpublished report [December 1987 ], Stadtplanungsamt Hildesheim).

${ }_{44}$ Andreas Hartmann, 'Nazi-Terror vor 50 Jahren: Ein Mahnmal soll erinnern', Kehrwieder, 29 March 1987.

${ }_{45} 5^{`}$ Das neue Denkmal ist bis zum 9. November in Holzkiste verpackt', Hildesheimer Allgemeine Zeitung, I5 October 1988.

${ }^{46} \mathrm{In}$ a survey of Holocaust memorials, Hubertus Adam notes approvingly that Gerz's memorial is schändungsresistent-it repels any attempt to defile it ('Bestimmtheit, Unbestimmtheit, Unsichtbarkeit: Wirkungen und Wirkungsbedingungen neuester NSMahnmäler' in Denkmäler: Ein Reader für Unterricht und Studium, edited by Eberhard Grillparzer, Günter Ludig and Peter Schubert [Hannover: Verlag Bund Deutscher Kunsterzieher, 1994], 36).

${ }_{47}^{4}$ For the text of the speeches and prayers, see Hermann Siemer, Hoffnung voll Unsterblïhkeit: Das Mahnmal für die Synagoge am Lappenberg in Hildesheim: Entstehung, Gestaltung, Deutung (Hildesheim: Bernward-Verlag, I989).
${ }^{8}$ Siemer, Hoffnung voll Unsterblichkeit, 93; for the debate which followed Siemer's speech, see, for example, "'Typische konservative Fehlleistung"?', Hildesheimer Allgemeine

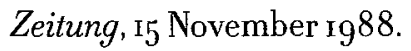

${ }^{49}$ Hildesheimer Allgemeine Zeitung, 29 July I957.

${ }_{50}$ ' "Die Zeit ist reif für eine jüdische Gemeinde in Hildesheim"', Hildesheimer Allgemeine Zeitung, 4 February 1997.

${ }^{51}$ See Irene Alger, Günter Peters, Anja Gerdes, Friedrich-Wilhelm Rogge, Frank Timmermann and Dirk Addicks, Verfolgung der jüdischen Bürger/innen Hildesheims: Hintergründe, Berichte, Dokumente (Hildesheim: Vereinigung der Verfolgten des Naziregimes-Bund der Antifaschisten, Kreisvereinigung Hildesheim, 1988), 59-62.

${ }^{52}$ Taped interview with Peter Hirschfeld, Bockenem, 5 May 1997.

${ }^{53}$ See 'Klinkerbauten sollen kleineren Häusern weichen', Hildesheimer Allgemeine Zeitung, Io February 1986.

${ }^{54}$ Guy Stern: "Ihr seid das Saatkorn einer neuen Welt"', Hildesheimer Allgemeine Zeitung, Io November 1988 .

${ }_{55}$ Notes about memorials in Hildesheim, provided by Kulturamt der Stadt Hildesheim, n.d. [I996].

${ }^{56}$ Robert Musil, Posthumous Papers of a Living Author, translated by Peter Wortsmann (Hygiene, Colorado: Eridanos Press, 1987), 6r.

${ }^{57}$ See, for example, Klaus Neumann,

'Remembering victims and perpetrators', UTS Review (forthcoming, 1998).

$5^{8}$ Zygmunt Bauman, Postmodern Ethics (Oxford: Blackwell, I993), especially chapter 2.

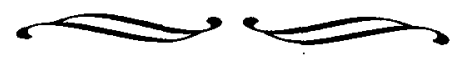

